Benignus Józef Wanat OCD

\title{
Architektura i wyposażenie kościoła i klasztoru Karmelitów bosych w Wiśniczu
}

\section{Historia budowy klasztoru}

Stanisław Lubomirski (1582-1649), podczaszy koronny, po nagłej śmierci hetmana wielkiego litewskiego Jana Karola Chodkiewicza w obozie pod Chocimiem, przejął dowództwo nad armią polską i litewską, liczącą ok. 75 tys. wojska w wojnie z Turcją. Turecka zaś armia Osmana II liczyła ponad 200 tys. wojska. Lubomirski, widząc ogromne zagrożenie i militarną przewagę nieprzyjaciela, złożył ślub: „jeśli Bóg pobłogosławi orężowi polskiemu, to ja w dobrach swoich w Wiśniczu wybuduję świątynię Bogu Zwycięscy, Zbawicielowi Jezusowi Chrystusowi, wraz z klasztorem Karmelitów bosych - reformy św. Teresy"”. Regimentarz nie zawiódł się w nadziei. Armia polska pod Chocimiem nie tylko wytrzymała oblężenie, ale i odparła zacięte szturmy wroga. „Sułtan zrażony brakiem męstwa swych żołnierzy, zdając sobie sprawę, iż zdobycie taboru [polskiego] jest raczej niemożliwe, myślał już o zakończeniu wyprawy” - napisał turecki kronikarz Mustafa Naim². Sułtan zawarł pokój: Polacy zobowiązali się

1 Biblioteka Zakładu Narodowego im. Ossolińskich we Wrocławiu, rkps 1871/I: Relatio fundationis conventus visnicensis Salvatoris Carmelitarum Discalceatorum cum annalibus ejusdem monasterii 1624-1719 [dalej: Kronika klasztoru], k. 3v.; Archivio Generale dei Carmelitani Scalzi, Roma, Corso d'Italia 38, Plut. 92 p: Origo fundationis conventus Salvatoris Carmelitarum discalceatorum Visnicii in Polonia [dalej: Origo fundationis], s. 2. Zobacz też wzmiankę o złożonym ślubie w dziełach św. Teresy od Jezusa, dedykowanych hr. Stanisławowi Lubomirskiemu: Opera s. Matris Teresae de Jesu Carmelitarum Discalceatorum et Discalceatarum Fundatricis [...]. Coloniae Agripinae 1626, apud Joannem Kinckium.

2 Chocim - Chotin (1621). [Fragmenty kroniki tureckiej Mustafy Naima]. Opr. M. Mnikowska, W. Walecki. Kraków-Nowy Wiśnicz 2005, s. 36. 
powstrzymywać od napadów Kozaków, a Turcy Tatarów3. Chocim miał pozostać w posiadaniu Turcji ${ }^{4}$.

Lubomirski, powracając z pola walki do Wiśnicza, zatrzymał się w krakowskim klasztorze karmelitów bosych pw. św. św. Michała i Józefa w celu uzgodnienia ślubowanej fundacji. Zarząd prowincji karmelitów bosych nie chciał przyjąć tej fundacji z obawy przed wpływem magnackiego dworu na życie zakonnes. Przeor tegoż klasztoru o. Piotr od św. Andrzeja Kordoński poradził Lubomirskiemu, aby zwrócił się w tej sprawie do Definitorium Generalnego w Rzymie ${ }^{6}$. Prośbę Lubomirskiego pozytywnie zaopiniował i poparł o. przeor Kordoński w listach do przełożonego generalnego o. Macieja Hurtados de Mendozy, znanego w Polsce i zasłużonego przeora pierwszego klasztoru w Krakowie (1605) i pierwszego prowincjała polskiej prowincji karmelitów bosych (1617) oraz do o. Pawła Szymona (od Jezusa i Maryi) Rivaroli przebywającego w Polsce przez pół roku na przełomie 1604 i 1605 w drodze na misję do Persji. Obydwaj zaprzyjaźnieni byli ze Stanisławem Lubomirskim, dobroczyńcą klasztoru św. św. Michała i Józefa w Krakowie. O. Paweł Szymon Rivarola w liście pisanym w Rzymie 5 lutego 1622 wyraził wielką radość z tej fundacji, powiadamiając o. Kordońskiego, że Definitorium Generalne wszystkimi głosami przyjęło i zatwierdziło fundację w Wiśniczu7. Urzędowo i formalnie przyjęto ją na sesji 8 lutego 1622 roku z tym warunkiem, że wspólnota zakonna zamieszka w Wiśniczu po ukończeniu budowy klasztoru8.

Po uzyskaniu zgody i zatwierdzenia fundacji od biskupa krakowskiego Marcina Szyszkowskiego Lubomirski przystąpił do budowy klasztoru. Za najgodniejsze miejsce dla realizacji swego ślubu uznał wzniesienie położone $\mathrm{w}$ kierunku południowym od swego pałacu, gdzie znajdował się park zamkowy z winnicami, egzotycznymi drzewami i kwietnikami. Był to najpiękniejszy zakątek Wiśnicza9 . Zlecił swojemu nadwornemu architektowi Maciejowi Trapoli ${ }^{10}$ przygotowanie

3 A. Lewicki, Zarys historii Polski. Warszawa [ok. 1920]' , s. 201.

4 W. Konopczyński, Dzieje Polski nowożytnej. Warszawa 2003, s. 261.

5 Kronika klasztoru, k. 4-5.

6 Tamże; Origo fundationis, k. 4.

7 Kronika klasztoru, k. 5.

8 Acta Definitorii Generalis OCD Congregationis S. Eliae (1605-1658). Wyd. A. Fortes OCD. W: Monumenta historica Carmeli Teresiani. Subsidia 3. Romae 1985, s. 86.

9 B. J. Wanat, Zakon Karmelitów Bosych w Polsce. Klasztory karmelitów i karmelitanek bosych 1605-1975. Kraków 1979, s. 348.

10 Maciej Trapola, architekt nadworny Stanisława Lubomirskiego, pochodził z Włoch, prawdopodobnie z miejscowości Portogruaro. Kierował budową klasztoru i kościoła Zbawiciela 
i opracowanie projektu budowy klasztoru oraz kierowanie budową z uwzględnieniem przepisów zakonu i zatwierdzonego planu dla polskiej prowincji karmelitów bosych ${ }^{11}$.

Poświęcenia i wmurowania kamienia węgielnego dokonał biskup pomocniczy krakowski Tomasz Oborski w maju $1622 \mathrm{roku}^{12}$. Fundator zgromadził potrzebne do budowy materiały oraz licznych pracowników, rzemieślników i tureckich jeńców do kopania rowów pod fundamenty. Po 8 latach pracy klasztor z wyjątkiem kościoła był na ukończeniu. Fundator, pragnąc widzieć w swojej fundacji zakonników, poprosił o. Michała od Zwiastowania NMP (Michael a Vidarte), prowincjała, o przysłanie zakonników na stały pobyt do Wiśnicza. Ze względu na wielkie zawilgocenie nowicjackiego klasztoru w Krakowie, spowodowane wylewami Wisły oraz podjęcie budowy nowego klasztoru murowanego na innym miejscu, o. Ferdynand a S. Maria (Martinez 1558-1631), przełożony generalny zakonu, aktem z 22 czerwca 1630 roku zezwolił na przeniesienie nowicjatu do Wiśnicza ${ }^{13} .26$ maja 1630 roku w uroczystość Świętej Trójcy miała miejsce introdukcja 16 karmelitów bosych w białych płaszczach do nowego klasztoru. Rozpoczęła się procesją eucharystyczną z kościoła parafialnego pod przewodnictwem bp. Marcina Szyszkowskiego, przy udziale licznego duchowieństwa, szlachty, wojska, orkiestry i chóru. W czasie procesji chór śpiewał pieśni na zmianę z grającą orkiestrą, a $\mathrm{z}$ fortecy zamkowej grzmiały działa. Cała droga udekorowana była kwiatami, religijnymi symbolami i napisami. Procesja przybyła do klasztornej kaplicy bogato wystrojonej i wyposażonej, z trzema srebrnymi figurami na ołtarzu - Chrystusa Salwatora, Matki Bożej i św. Teresy od Jezusa. Pontyfikalnej mszy św. przewodniczył bp Szyszkowski, a okolicznościowe kazanie wygłosił wielki przyjaciel karmelitów ks. dr Sebastian Nuceryn, kaznodzieja katedralny. Po mszy św. nastąpiła ceremonia wręczenia kluczy przez

\footnotetext{
karmelitów bosych w Wiśniczu od fundamentów aż do ukończenia budynku. Za jego zasługi kapituła klasztoru 31 grudnia 1637 roku postanowiła urządzić mu pogrzeb i pogrzebać jego ciało w krypcie grobowej kościoła Zbawiciela. Zob. APKB, sygn. AKWI 1: Acta capituli conventus..., k. 15 v.; S. Łoza, Architekci i budowniczowie w Polsce. Warszawa 1954, s. 313; P. S. Szlezynger, Kościót Karmelitów Bosych w Wiśniczu Nowym. „Kwartalnik Architektury i Urbanistyki” T. 33: 1988, z. 2, s. 115. (Autor w pełni wykorzystał wcześniej wydaną pracę: Klasztor Chrystusa Zbawiciela w Wiśniczu. W: B. J. Wanat, Zakon Karmelitów Bosych w Polsce..., s. 347-372).

${ }^{11}$ B. J. Wanat, Zakon Karmelitów Bosych w Polsce..., s. 93-99; tenże, Z dziejów zakonnego budownictwa barokowego w Małopolsce. Kraków 2006, s. 23-44.

${ }_{12}$ Kronika klasztoru, k. 5-8.

13 Bibl. Ossol., rkps 1877: Acta primi capituli generalis..., s. 107.
} 
fundatora Lubomirskiego o. Cyrylowi od św. Franciszka (1586-1658), przeorowi nowego klasztoru, a następnie w zamku odbyła się uczta dla gości. Po południu odśpiewane zostały nieszpory z kazaniem o. Hieronima od św. Jacka Cyrusa, lektora teologii w Lublinie ${ }^{14}$. Dla upamiętnienia tej uroczystości i zwycięstwa chocimskiego, młodzież szkoły Nowodworskiego z Krakowa wręczyła fundatorowi klasztoru drukowany poemat panegiryczny Fluminis impetus ${ }^{15}$ jako podziękowanie za zwycięstwo pod Chocimiem i za wypełnienie złożonego ślubu w postaci okazałego klasztoru Zbawiciela.

W 1635 roku ukończono budowę kościoła. Fundator nie szczędził pieniędzy na jej wystrój. Pragnął, aby kościół i klasztor pozostał pomnikiem zwycięstwa pod Chocimiem na wieczne czasy oraz aby świadczył przyszłym pokoleniom o wspaniałomyślności, fortunie i zasługach Lubomirskiego. Konsekracja kościoła pod wezwaniem Chrystusa Salwatora odbyła się 1 lipca 1635 roku z królewskim przepychem $^{16}$. Na samą dekorację świątyni fundator wydał 6 tys. zł. Wnętrze świątyni lśniło od złota i srebra. W głównym ołtarzu stały wysokie na dwa łokcie srebrne statuy Chrystusa Zbawiciela, Matki Bożej i św. Teresy od Jezusa oraz pozłacane relikwiarze. Na ołtarzu paliło się 30 świec woskowych w bogatych kandelabrach. Pomiędzy nimi stały złote i srebrne wazony z kwiatami. Uroczystość uświetniała kapela sprowadzona z zamku krakowskiego. W wigilię konsekracji kościoła odbyło się uroczyste nabożeństwo z procesją przy udziale kapeli i huku dział na zamku. W tym też dniu przeniesiono procesjonalnie z kaplicy zamkowej do kościoła trumnę z ciałem zmarłej w 1622 roku żony fundatora Zofii Ostrogskiej. Pochowano ją w nowej bogatej trumnie w mauzoleum - grobowcu fundatorskim. O godzinie pierwszej po północy sztuczne ognie ogłosiły

${ }_{14}$ Klasztory Karmelitanek Bosych w Polsce, na Litwie i Rusi. T. 1: Kraków - klasztor św. Marcina. Wyd. Rafał Kalinowski OCD św. Kraków 1904, s. 232-233. Wydawca kroniki klasztornej załączył $\mathrm{w}$ aneksie na s. 230-235 przekład z łaciny na język polski z archiwum generalnego w Rzymie, sygn. Plus 92 p.: Origo fundationis...: Opis przebiegu fundacji klasztoru Zbawiciela na Górze Wiśnicz. Łacińska kopia tego opisu znajduje się w Archiwum Krakowskiej Prowincji Karmelitów Bosych w Czernej, pod sygn. AP 1: Fasciculus annorum..., s. 223-254.

15 Fluminis impetus Illustrissimo ac Magnifico Domino D. Stanislao Lubomirski, comiti in Wiśnicz, palatino terrarum Rusiae, Sandomirensi, Scepusiensi, Białocerkieviensi etc. Capitaneo. Dum primum, in templum (quod magnifice ad propugnaculum Visnicense erexit, et pie, ob. Repressam, Osmani Turcarum imperatoris ferocissimi, potentiam, Deo Salvatori vovit) sacratissimam Carmelitarum Discalc. familiam, solemni ritu, introduceret a nobili et studiosa iuventute scholarum Novodvors. Perpetui honoris et observan. Ergo consecratus ac DD. Cracoviae 1630, in typographia Matthiae Andreoviensis. Estr XIV, s. 489.

${ }^{16}$ Kronika klasztoru, k. 8-9; Klasztory Karmelitanek Bosych w Polsce, na Litwie i Rusi..., s. 233. 
uroczysty dzień w Wiśniczu. Centralną uroczystością była konsekracja kościoła pod wezwaniem Chrystusa Zbawiciela, której dokonał bp Tomasz Oborski, sufragan krakowski, przy udziale licznego duchowieństwa i zaproszonych na tę uroczystość gości ${ }^{17}$.

\section{Architektura klasztoru i kościoła Chrystusa Zbawiciela ${ }^{18}$}

\section{Architektura klasztoru}

W celu wzniesienia tego klasztoru zarząd prowincji wyznaczył do realizacji projekt większego klasztoru, zatwierdzonego przez Definitorium Generalne w Rzymie 14 stycznia 1622 roku $^{19}$ dla polskiej prowincji karmelitów bosych, z zachowaniem wymiarów ustalonych w konstytucjach zakonu ${ }^{20}$.

Klasztor jest murowany z cegły i kamienia, wczesnobarokowy, zbudowany w kształcie regularnego czworoboku o wymiarach $61 \times 62 \mathrm{~m}$, dwukondygnacyjny, podpiwniczony, z trzema dziedzińcami wewnętrznymi i wnętrzami sklepionymi kolebkowo i krzyżowo. Przylega do południowej i zachodniej części kościoła. Zewnętrzna i wstępna część klasztoru usytuowana jest obok fasady kościoła, skierowanej na północ w stronę zamku Lubomirskich. Portal wejściowy

17 Tamże, k. 10-11; B. J. Wanat, Zakon Karmelitów Bosych w Polsce..., s. 351.

18 Podstawa źródłowa: Kronika klasztoru, k. 1-15; Constitutiones Fratrum Discalceatorum Congregationis s. Eliae Ordinis Beatissimae Virginis Mariae de Monte Carmelo. Romae 1631, apud Franciscum Corbellettum, s. 72-79; Biblioteka Naukowa PAU i PAN w Krakowie, rkps 907: Inventarium universale bonorum conventus Visnicensis Carmelitarum Discalceatorum anno 16451671; APKB w Czernej, sygn. AKWI 1: Acta capituli conventus visnicensis... ab A. D. 1630; APKB w Czernej, Dokumentacja fotograficzna klasztoru; J. Langman, Dawne klasztory oo. karmelitów bosych w Polsce - Wiśnicz. „Głos Karmelu” R. 8: 1934, nr 10, s. 374; B. J. Wanat, Klasztor Chrystusa Zbawiciela w Wiśniczu. W: Zakon Karmelitów Bosych w Polsce. Klasztory karmelitów i karmelitanek bosych 1605-1975. Kraków 1979, s. 347-372; M. Brykowska, Architektura karmelitów bosych w XVIIXVIII wieku. Warszawa 1991; P. S. Szlezynger, Kościół Karmelitów Bosych w Wiśniczu Nowym..., s. $113-139$.

19 Acta Definitorii Generalis OCD Congregationis S. Eliae (1605-1658)..., s. 81.

20 Constitutiones Fratrum Discalceatorum..., s. 72-77; Instructiones Fratrum discalceatorum Congregationis s. Eliae Ordinis Beatissimae Virginis Mariae de Monte Carmelo. Romae 1635, ex officina L. Grignani, s. 82-91; B. J. Wanat, Zakon Karmelitów Bosych w Polsce..., s. 97. 
prowadził do furty i pokoi gościnnych. Ta część klasztoru koncentrowała się wokół większego dziedzińca wewnętrznego $(23 \times 24 \mathrm{~m})$, pośrodku którego znajdowała się zadaszona studnia $\mathrm{z}$ kołowrotem. Z bramy klasztornej wchodziło się na krużganek opasujący $z$ trzech stron większe podwórze. Po stronie zachodniej korytarza były cele gościnne i furtiana, czyli portiera. Za nimi po tej samej stronie na parterze był mały refektarz, sklepiony kolebkowo, przeznaczony dla pracowników i gości. Za nim z poprzecznego korytarza wejście do ogrodu, a za nim toalety i cele zakonne o wymiarach 3,20 ×3,20 ×3,20 m do końca korytarza po tej samej stronie i po stronie południowej. Pomiędzy wewnętrznymi podwórzami przy środkowym korytarzu znajdowała się kuchnia (8,64 m), zmywalnia naczyń, magazyn kuchenny i refektarz dł. 15,84 m, wys. 5,76 m, a pośrodku między wschodnim i zachodnim podwórzem wewnętrznym były trzy pomieszczenia na składy klasztorne oraz toaleta w pobliżu zakrystii. Na parterze skrzydła wschodnio-południowego krużganki wokół mniejszego podwórza prowadziły do cel i dwóch salek w południowym narożniku, do klatki schodowej na piętro oraz do brackiej kaplicy (ok. $12 \mathrm{~m} \mathrm{~d}$.), usytuowanej po stronie wschodniej w przedłużeniu składu kościelnego, czyli skarbca. W przedłużeniu prezbiterium kościoła był letni chór zakonny (dł. 9,60 m) z dwoma portalami marmurowymi prowadzącymi do kościoła. Obok prezbiterium od strony klasztoru mieściła się zakrystia (szer. 10,80 m), a od strony wschodniej skład kościelny, czyli skarbiec, z przejściami do transeptu kościoła. Na piętrze klasztoru znajdowały się cele mieszkalne dla zakonników, sala rekreacyjna ojców i braci, sala wykładowa dla nowicjuszy lub studentów, kaplica dla nowicjuszy, biblioteka i archiwum klasztoru. Lokal dla biblioteki według konstytucji powinien mieć $12 \mathrm{~m}$ długości, zatem mogła się ona znajdować nad kuchnią klasztorną. Nad kaplicą bracką prawdopodobnie mieściła się kaplica nowicjatu lub studentatu. Nad zakrystią usytuowany był chór zakonny. Dwuspadowe dachy klasztoru pokryte były blachą.

\section{Architektura kościoła}

Kościół Chrystusa Salwatora usytuowany był w północno-wschodniej części klasztoru, murowany, na rzucie krzyża łacińskiego, fasadą zwrócony na północ w stronę zamku Lubomirskich. Szerokość nawy kościoła zgodnie z konstytucjami wynosiła 40 palm ${ }^{21}$, czyli 9,60 m, a proporcjonalna długość $34 \mathrm{~m}$. Korpus

${ }^{21} 1$ palma budowlana (jednostka miary) $=24 \mathrm{~cm}$; zob. Constitutiones Fratrum Discalceatorum..., Romae 1631, s. 248 - rysunek miary palmy, czyli piędzi. 
był jednonawowy, po bokach z rzędem kaplic bocznych, połączonych ze sobą wąskimi przejściami i otwartych do głównej nawy arkadami ujętymi w archiwolty, wspartymi na filarach. Nawa i prezbiterium dwuprzęsłowe. Elewacje boczne kościoła podzielono pilastrami, z głowicami korynckimi. Na nich wsparty bogaty fryz, obiegał całe wnętrze kościoła, wykonany ze stiuku, a skomponowany z panopliów o motywach tureckich, jak krzywe szable, turbany, kotły wojenne, armaty i zbroja. Fryz, wykonany na wysokim poziomie estetyki dekoracyjnej, miał przypominać zwycięstwo chocimskie. Powyżej fryzu znajdował się potężny gzyms bogato rozczłonkowany, zdobiony wolimi oczkami, ząbkami i perełkami. Ponad łukami bocznych kaplic i w prezbiterium wykonano bogate dekoracje stiukowe na wzór supraportalowych z kartuszami, owalnymi otworami do pomieszczeń nad bocznymi kaplicami (coretti), nasadnikami zwieńczonymi tympanonami, otoczonymi wolutami z kulami. W bocznych narożach i na podniebiach łuków znalazły się dekoracje roślinno-kwiatowe. Na przyozdobienie wnętrza kościoła sztukaterią oraz na jego bogate wyposażenie, argenterię i kościelne paramenty fundator klasztoru Stanisław Lubomirski uzyskał dyspensę od obowiązujących przepisów zakonnych dotyczących budownictwa i wystroju kościoła i wyposażenia. Kapituła Generalna Zakonu Karmelitów Bosych 11 maja 1632 roku, doceniając realizację złożonego ślubowania za odniesione zwycięstwo nad zagrażającą chrześcijańskiej Europie potęgą islamskiej Turcji, wszystkimi głosami swoich członków przychyliła się do prośby fundatora klasztoru ${ }^{22}$. W kaplicach zastosowano porządek toskański. Kościół sklepiony kolebkowo z płaskimi gurtami w przedłużeniu pilastrów, a w skrzyżowaniu transeptu - krzyżowo, z oknami w lunetach. W dekoracji sklepień nawy, transeptu i prezbiterium zastosowano podziały geometryczne, a mianowicie owale i kartusze ujęte w prostokątne obramowania, zaś na skrzyżowaniu transeptu - geometryczną dekorację żagielkową. Sztukaterie kościoła projektował i wykonał Jan Chrzciciel Falconi wraz ze swoim warsztatem dekoratorskim, zatrudniony wtedy na zamku Lubomirskiego ${ }^{23}$.

Fasada kościoła zbudowana została $\mathrm{z}$ kamienia ciosowego, według zmodyfikowanego typu il Gesù dla kościołów karmelitańskich, dwukondygnacyjna, harmonijnie rozczłonkowana zdwojonymi pilastrami w przęśle środkowym na osi nawy dolnej kondygnacji w porządku toskańskim, a w górnej kondygnacji

${ }^{22}$ Acta Capituli Generalis OCD Congregationis s. Eliae. (dalej: Acta Cap. Gen) Vol. 1: (16051641). Wyd. A. Fortes. W: Monumenta historica Carmeli Teresiani. T. 11. Romae 1990, s. 282.

${ }_{23}$ A. Bochnak, Giovanni Battista Falconi. Kraków 1925, s. 8-9. 
w porządku jońskim. W głównym portalu dwie kolumny dźwigały belkowanie z przerwanym przyczółkiem $\mathrm{z}$ herbem Lubomirskich $\mathrm{w}$ środku tympanonu. Poniżej w nadprożu umieszczono miedzianą pozłacaną tablicę $z$ napisem dedykacyjnym świątyni. Ponad portalem znajdowało się okno z kratami w obramieniu kamiennym, z trójkątnym przyczółkiem. W bocznych przęsłach natomiast konchowe nisze zamknięte kluczem, a nad nimi owalne okienka z kratkami. Górną kondygnację ozdobiła przeszklona bramka z żelaznym gankiem, spływy wolutowe po bokach oraz rzeźby Sebastiana i Stanisława Lubomirskich na cokołach. $\mathrm{Na}$ szczycie wieńczącego przyczółku umieszczono dużych rozmiarów posąg Chrystusa Zbawiciela. Za kurtyną fasady wznosiły się czworoboczne, a u szczytu ośmioboczne wieże z dzwonami, nakryte barokowymi hełmami, niezharmonizowane z całością, jakby sztucznie doczepione. Boczne elewacje na zewnątrz świątyni zostały rozczłonkowane zdwojonymi pilastrami z gzymsem dachowym wspartym na ciosowych konsolach nad bocznymi nawami. Ściany zamykające ramiona transeptu były trzykondygnacyjne $\mathrm{z}$ podziałami architektonicznymi, zwieńczone edikulami z trójkątnym przyczółkiem i ujęte spływami po bokach, krzyżami na szczytach i kulami na bocznych cokolikach. Dwuspadowe dachy zostały pokryte miedzianą blachą.

Cały zespół architektury klasztoru otoczono fortyfikacjami nowowłoskimi, utworzonymi z czterech bastionów pięciokątnych na osiach poprzecznych i z czterech bastionów trójkątnych na osiach przekątnych ${ }^{24}$. Mury bastionów kleszczowych umocnione były od wewnątrz nasypem ziemnym. Naroża wieloboku wysunięte $\mathrm{w}$ przedpole stanowiły główny element obrony w czasie napadu nieprzyjacielskiego. Fortyfikacje klasztoru sprzężone były w system obronny zamku Lubomirskich, oddalony o $300 \mathrm{~m}$ na północ. W północno-zachodnim bastionie w 1639 roku wybudowano mieszkania, tzw. plebanię do przyjeżdżających do klasztoru gości ${ }^{25}$. Obok budynku w murze obronnym znajduje się brama wjazdowa do klasztoru, flankowana boniowanymi pilastrami z trójkątnym przyczółkiem, herbem Szreniawa i marmurową tablicą z napisem: „UT SACRIS AEDIBUS ATQ[UE] COENOBIO A SE CONDITIS INSTRUCTIS DOTATIS, PALATINUS ET GENERALIS CAP[ITA]NEUS CRACOVIEN[SIS] HONORI-

${ }_{24}$ J. E. Dutkiewicz, Powiat bocheński. W: Katalog zabytków sztuki w Polsce. T. 1: Województwo krakowskie. Pod red. J. Szablowskiego. Warszawa 1953, s. 64; P. S. Szlezynger, Fortyfikacje klasztoru karmelitów bosych w Wiśniczu Nowym. „Kwartalnik Architektury i Urbanistyki” T. 28: 1983, z. 2, s. $143-160$.

${ }^{25}$ Kronika klasztoru, k. 16. 
BUS MUTATIS, PIETATE IMMUTABILI, SECURITATE[M] P[R]AESTARET MURO HOC CINXIT, ANNO INCARNATI[ONIS] CHRISTI MDCXL" ${ }^{26}$.

\section{Wyposażenie kościoła i klasztoru}

Kościół posiadał 8 ołtarzy, z tych 3 dużych rozmiarów: Chrystusa Zbawiciela w prezbiterium i Matki Bożej oraz św. Teresy od Jezusa w ramionach transeptu. W kaplicach naw bocznych ołtarze poświęcone były w XVII wieku: św. Annie, św. Józefowi, św. Michałowi Archaniołowi oraz męczennikom - św. Stanisławowi i Sebastianowi. Ósmy ołtarz - Chrystusa Ukrzyżowanego - znajdował się w grobowym mauzoleum Lubomirskich w krypcie pod transeptem kościoła.

Główny ołtarz zbudowany był z marmuru i drewna. Składał się z dwóch oddzielnych części, perspektywicznie tworzących całość o znamionach teatralizacji wnętrza. Mensa ołtarzowa $\mathrm{z}$ dwoma bocznymi portalami z marmuru usytuowana była w połowie prezbiterium, podniesionego o trzy stopnie powyżej nawy kościoła. Na mensie ołtarzowej stało bogate, hebanowe tabernakulum, precyzyjnie wykonane w formie architektonicznej świątyńki, z 10 kolumienkami i w srebrze odlewanymi kapitelami. Tabernakulum strzegło i adorowało 5 aniołów odlanych w srebrze. Powyżej tabernakulum umieszczony był tron do wystawiania Sanctissimum, zamykany drzwiczkami ze srebrnej blachy, zwieńczony srebrnym krzyżem. Między tronem a tabernakulum umieszczono herb Szreniawa, a nieco niżej srebrnego pelikana, stojącego w gnieździe z trojgiem pisklą ${ }^{27}$.

Druga część ołtarza znajdowała się w głębi nad stallami, na czołowej ścianie prezbiterium. Nadstawa ołtarzowa miała dwie kondygnacje: dolna złożona była z olbrzymich kolumn i proporcjonalnego do nich obrazu w retabulum Chrystusa Zbawiciela w bogato złoconych ramach; wyższa kondygnacja miała mniejszy obraz też w złoconej ramie w nasadniku zwieńczonym przyczółkiem. W ołtarzu tym wyeksponowane były trzy srebrne statuy: Chrystusa Zbawiciela,

${ }^{26}$ „Aby kościołowi i klasztorowi, przez siebie założonym, wybudowanym i uposażonym wojewoda i generalny starosta krakowski, godnościami zmienny, ale dla pobożności niezmienny - zapewnić bezpieczeństwo wszystko murem otoczył. Roku Wcielenia Chrystusa 1640”. Zob. P. S. Szlezynger, Dawny kościół Karmelitów Bosych w Wiśniczu. Kraków 2000, s. 7.

${ }_{27}$ Szczegółowy opis wyposażenia kościoła i zakrystii zob. Biblioteka Naukowa PAU i PAN w Krakowie, rkps 907: Inventarium universale bonorum conventus Visnicensis Carmelitarum Discalceatorum anno 1645-1671; B. J. Wanat, Zakon Karmelitów Bosych w Polsce..., s. 353-362. 
Matki Bożej i św. Teresy od Jezusa, wykonane w zakładzie złotniczym Andrzeja Malkensena w Krakowie.

Ołtarze boczne $\mathrm{w}$ transepcie, podobnie jak w prezbiterium, oddzielone były od centralnej nawy marmurowymi balustradami z drzwiczkami z brązu. Oba ołtarze wykonane z drewna sięgały zwieńczeniem aż do gzymsu kościoła. Każdy z nich miał po cztery duże złocone kolumny z ornamentem roślinno-geometrycznym. Górną część ołtarzy zdobiły barokowe postacie czterech aniołów: dwu w pozycji stojącej i dwu siedzących. Całość kompozycji zamykały retabula $\mathrm{z}$ mniejszymi obrazami w rzeźbionych ramach, flankowane kolumienkami, na których wspierał się przerwany wieńczący przyczółek. Niższe kondygnacje nawiązywały do stylu renesansowego. W bocznych niszach ustawiono statuy świętych. W ołtarzu św. Teresy - rzeźby św. św. Wojciecha i Stanisława, biskupów męczenników, patronów Polski. W ołtarzu zaś Matki Bożej - statuy Eliasza i Elizeusza, proroków. W tym ołtarzu znajdował się duży obraz Wniebowzięcia NMP. Obraz ten posiadał srebrną sukienkę ze złoconymi promieniami, sprawioną przez konwent w 1706 roku jako wotum wdzięczności za opiekę nad klasztorem w czasie inwazji szwedzkiej ${ }^{28}$. W zwieńczeniu tegoż ołtarza mniejszy obraz przedstawiał scenę Zwiastowania NMP. W ołtarzu św. Teresy duży obraz przedstawiał scenę Chrystusa przebijającego gwoździem dłoń św. Teresy na znak łaski zjednoczenia. Obrazy do kościoła malowali na zamówienie fundatora Mateusz Ingerman $\mathrm{z}$ Antwerpii ${ }^{29} \mathrm{i}$ Jose Ribera.

Cztery ołtarze w kaplicach bocznych kościoła były małych rozmiarów. Posiadały stiukową dekorację, z bogatym obramieniem obrazów. W jednej z tych kaplic znajdował się słynący łaskami obraz św. Józefa, który obecnie jest w kościele parafialnym w Wiśniczu. Przyozdobiony był srebrną pozłacaną sukienką wotywną. Przy tej kaplicy erygowano Bractwo św. Józefa, mocą indultu papieża Klemensa IX w 1670 roku $^{30}$. Święty Józef otaczany był wielką czcią. Kronikarz klasztoru zanotował, że 19 marca 1659 roku rozdano 3 tys. komunii św. ${ }^{31}$.

Od centralnej nawy kaplice boczne oddzielały marmurowe balustrady. Posadzka w kościele była marmurowa. Dwie ambony z wyobrażeniem św. Eliasza z ognistym mieczem, stylowe konfesjonały i ławki dopełniały całości wnętrza.

28 APKB, sygn. AKWI 1: Acta capituli conventus Visnicensis..., s. 254.

29 Kronika klasztoru, k. $15 \mathrm{v}$.

3o B. J. Wanat, Kult św. Józefa Oblubieńca NMP u karmelitów bosych w Krakowie. Kraków 1981, S. 29 .

${ }^{31}$ Kronika klasztoru, k. 42v. 
Nad portalem wejściowym usytuowano chór muzyczny z organami. Przy kościele w XVIII wieku działała kapela muzyczna.

Naprzeciw ambony, z boku ołtarza Matki Bożej, schody otoczone pozłacaną balustradą prowadziły do kaplicy podziemnej i grobowca fundatorskiego. Dekorację stiukową w tej kaplicy wykonał Jan Chrzciciel Falconi. Był tam ołtarz Chrystusa Ukrzyżowanego. W ołtarzu krzyż z korpusem Chrystusa i statuy Matki Bożej i św. Jana Ewangelisty odlane były ze srebra ${ }^{32}$. Z prawej strony ołtarza prowadziło wejście do ozdobionego grobowca fundatorów. Znajdowało się w nim w metalowych i marmurowych sarkofagach 10 osób $\mathrm{z}$ rodziny fundatorskiej oraz kilka drewnianych trumien osób niezidentyfikowanych.

Z prawej strony prezbiterium była zakrystia, przyozdobiona sztukaterią i polichromią wykonaną w 1639 roku przez Stanisława Kosteckiego z Krakowa ${ }^{33}$. Fundator hojnie ją wyposażył. Przez całe życie czuwał nad ozdobą kościoła. Często powtarzał karmelitom: „Patres, vos nihil soliciti sitis de his, quae spectant ad ornamentum ecclesiae et sacristiae. Munus sacristae meum erit, ego ipse horum curam geram" ${ }^{34}$. Według inwentarza z 1643 roku zakrystia posiadała znaczną ilość klejnotów, kosztownych paramentów kościelnych, szat liturgicznych, obrazów (na miedzianej blasze 18) i przedmiotów oraz naczyń liturgicznych ze złota i srebra, takich jak: monstrancja odlewana z Augsburga, 3 puszki, 10 kielichów z patenami, 10 relikwiarzy, statuy świętych, 34 kandelabry ${ }^{35}$ etc. W sumie wszystko srebro z kościoła i zakrystii ważyło marek 980, łutów 2015. W przeliczeniu na walutę kosztowało ono wówczas $38593 \mathrm{złp}^{36}$.

W chwili introdukcji karmelitów bosych do Wiśnicza fundator przekazał im $\mathrm{w}$ posiadanie gotowy klasztor $\mathrm{z}$ pełnym urządzeniem, przygotowanymi i umeblowanymi celami (nawet $z$ bielizną pościelową), refektarzem, wyposażoną w naczynia kuchnią oraz księgozbiór biblioteki liczący 300 tomów cennych dzieł w bogatej oprawie ${ }^{37}$. Zapewniając na przyszłość utrzymanie klasztoru, Stanisław Lubomirski, 7 października 1647 roku w Urzędzie Ziemskim w Proszowicach zapisał klasztorowi na wieczne czasy swoje dziedziczne wioski: Zegartowice,

32 Tamże, k. 60 .

33 Tamże, k. 15.

${ }_{34}$ Tamże, k. 8.

${ }_{35}$ Zob. Kronika klasztoru, k. 16; Inventarium universale..., k. 1-5; B. J. Wanat, Zakon Karmelitów Bosych w Polsce..., s. 358-362.

${ }^{36}$ Inventarium universale..., k. 17.

${ }_{37}$ Kronika klasztoru, k. 8; J. Długosz, Biblioteka klasztoru karmelitów bosych w Wiśniczu. „Archiwa, Biblioteki i Muzea Kościelne” T. 13: 1966, s. 93-111. 
Krzesławice, Kwastowice i Dąbie z przyległościami, z majątkiem Bigoszówka i częściami lasu dóbr Komorniki ${ }^{38}$. Wcześniej, bo już w 1624 roku w urzędzie starościńskim sądeckim zapisał karmelitom wioskę Leksandrowa, położoną na południe od klasztoru ${ }^{39}$.

W odpowiedzi na wspaniałomyślność Stanisława Lubomirskiego Kapituła Prowincjalna Karmelitów Bosych w Lublinie, 12 maja 1631 roku zobowiązała klasztor w Wiśniczu do następujących modlitw i religijnych praktyk na rzecz fundatora:

1. Codziennie na zawsze dwie msze św. za życia i po śmierci.

2. W każdą sobotę jedną mszę św. śpiewaną o Matce Bożej lub w inny dzień tygodnia.

3. Po śmierci fundatora takie same modlitwy, jak za zmarłego zakonnika w całej prowincji.

4. Na zawsze jedna msza św. w rocznicę śmierci.

5. Codziennie jedną godzinę modlitwy myślnej.

6. W każdy piątek wspólną dyscyplinę (samobiczowanie).

7. Codziennie po Nieszporach Litanię do NMP ${ }^{40}$.

Zakonnicy wypełniali te zobowiązania aż do kasaty klasztoru przez cesarza Józefa II w 1783 roku. Austriacy zamienili klasztor na więzienie dla przestępców politycznych; pełni on tę rolę bez przerwy do dziś. Natomiast okupanci niemieccy zniszczyli i rozebrali zabytkowy kościół w latach 1940-1942, jako symbol zwycięstwa Polski nad wrogami. W krypcie grobowej Lubomirskich ocalało 8 sarkofagów: 1 miedziany, 5 marmurowych i 2 drewniane oraz 2 trumny. W 1949 roku zostały one przewiezione do kaplicy zamku wiśnickiego ${ }^{41}$.

${ }_{38}$ Bibl. Ossol., rkps 91: Donatio bonorum Zegartowice ... etc., k. 220-224; tamże, rkps 4839/II: Liber iurium in quo erectio fundationis conventus Visnicensis firmatur, s. 22.

39 Bibl. Ossol., rkps 4839/II: Liber iurium..., s. 4.

${ }_{40}$ Kronika klasztoru, k. 9r.

${ }^{41}$ S. Fischer, Wiśnicz Nowy, jego przeszłość, zabytki i stan dzisiejszy. Warszawa 1967, s. 53. 


\section{Streszczenie}

\section{Architektura i wyposażenie kościoła i klasztoru Karmelitów bosych w Wiśniczu}

Ufundowany w Wiśniczu przez Stanisława Lubomirskiego (1582-1649) kościół Chrystusa Salwatora i klasztor Karmelitów bosych był dziękczynnym votum za zwycięstwo odniesione pod Chocimiem oraz szczęśliwe zakończenie wojny polsko-tureckiej w 1621 roku. Założenie klasztorne zostało wzniesione opodal rodowego zamku Lubomirskich w Wiśniczu wg planów Macieja Trapoli w latach 1622-1635. Konsekrowany 1 lipca 1635 roku kościół klasztorny pod wezwaniem Chrystusa Salwatora otrzymał bardzo bogate wyposażenie, podobnie jak i sam klasztor. Kościół wzniesiony wg reguł zakonu karmelitańskiego był budowlą murowaną, na rzucie krzyża łacińskiego, o zwróconym na południe dwuprzęsłowym prezbiterium oraz jednonawowym, także dwuprzęsłowym korpusie, otoczonym po bokach rzędem kaplic bocznych, połączonych ze sobą wąskimi przejściami i otwartych do głównej nawy arkadami ujętymi w archiwolty, wspartymi na filarach. Wnętrze ozdobiono bogatą dekoracją stiukową, wykonaną przez Jana Chrzciciela Falconiego, skomponowaną między innymi z panopliów o motywach tureckich, co bezpośrednio nawiązywało do zwycięstwa chocimskiego. Pod ramionami transeptu urządzono rodowe mauzoleum Lubomirskich z ołtarzem Ukrzyżowania. Niestety $\mathrm{w}$ wyniku zawieruch dziejowych nie przetrwało ani bogate wyposażenie kościoła, ani sama świątynia, zburzona przez niemieckiego okupanta w latach 1940-1942. Przylegający do kościoła od strony południowej i zachodniej klasztor był budowlą podpiwniczoną i murowaną. Wzniesiono go w stylu wczesnobarokowym na planie regularnego czworoboku o wymiarach $61 \times 62 \mathrm{~m}$, z trzema dziedzińcami wewnętrznymi i wnętrzami sklepionymi kolebkowo i krzyżowo. Budynek klasztoru po kasacie zakonu przez cesarza Józefa II w 1783 roku został zamieniony na więzienie.

\section{Summary}

Architecture and furnishings of the church and monastery of the Discalced Carmelites in Wiśnicz

Founded in Wisnicz by Stanisław Lubomirski (1582-1649), Christ the Saviour church and monastery of the Discalced Carmelites was a votive offering of thanks for the victory 
at Chocim and a happy ending of the Polish-Turkish war in 1621. The monastery was built near the Lubomirskis' ancestral castle in Wiśnicz according to the design by Maciej Tripoli between 1622 and 1635. Consecrated on 1 July 1635, both the abbey church, dedicated to Christ the Saviour, as well as the monastery were very richly furnished. The church, built according to the rules of the Carmelite Order, was a brick building, on the plan of the Latin cross with the south facing a two-span presbytery and a one-nave, twospan main body, flanked by a row of side chapels, interconnected by narrow passages and open to the main nave with arcades enclosed by archivolts and sustained by pillars. The interior was decorated with rich stucco decoration, made by John the Baptist Falconi, composed, among others, of panoplies of Turkish motifs, which directly referred to the victory at Chocim. Under the arms of the transepth the Lubomirskis ancestral mausoleum with the altar of the Crucifixion was built. Unfortunately, neither the rich furnishings of the church, nor the temple, destroyed by the German occupation in 1940-1942, survived the turmoil of history and was destroyed by the Nazis in 1940-1942. The monastery, adjacent to the church on the south and west, was a brick building with a basement. It was built in early Baroque style on the set of a regular square with dimensions 61 by $62 \mathrm{~m}$, with three internal courtyards and cross and tunnel vaulted interior. The monastery building, upon the dissolution of the order by Emperor Joseph II in 1783 was converted into a prison. 